\title{
VALUE CREATION THROUGH CSR AT STAKEHOLDERS LEVEL
}

\author{
Donatas Jonikas \\ Klaipeda university, Lithuania, donatas.jonikas@gmail.com \\ cross ${ }^{\text {ref }}$ http://dx.doi.org/10.5755/j01.em.17.2.2200
}

\begin{abstract}
In spite of the existing strong literature about the role of corporate social responsibility (CSR) in the aspects of environment and society, there is a significant gap about how CSR can create value for company stakeholders. In spite of Carroll's pyramid and 3C-SR model, there is a lack of holistic framework that exhibit the process of value creation for company stakeholders. The objective of this paper work is to identify theoretical possibilities of value creation through CSR for stakeholders, yet avoiding extensive discussions concerning value creation to common environment. Study shows that most likely only shared value creation through CSR seems to be sustainable. It's already foreseen that CSR will evolve and value creation through CSR will change and possibly implementation of CSR will become more oriented towards creation of shared value.
\end{abstract}

The employed research methods refer to scientific literature analysis and synthesis.

Keywords: corporate social responsibility, value creation, shared value, use value, stakeholders.

JEL Classification: D46, M14, M20.

\section{Introduction}

As noticed (Gholami, 2011; Valackienè \& Micevičienè, 2011), in spite of the existing strong literature about the role of corporate social responsibility in the aspects of environment and society, there is a significance gap about how corporate social responsibility (CSR) can create value for corporations and society. In spite of Carroll's pyramid and 3C-SR model, there is a lack of holistic framework that exhibit the process of value creation for organizations and society. The aim of this paper work is to develop assumptions on value creation through CSR at stakeholders level, yet avoiding extensive discussions concerning value creation to common environment.

\section{Theoretical background for dimension of value creation through CSR}

Many scholars (Lepak et al., 2007; Bowman \& Ambrosini, 2000) already have researched value creation in corporate (organization) level, therefore use and exchange value categories emerged. Generally it is agreed that new value is created when companies develop new ways of doing things using new methods, new technologies, and/or new forms of raw material. Bowman and Ambrosini (2000) introduced and differentiated two types of value at the organizational level of analysis: use value and exchange value. Lepak, Smith and Taylor (2007) have focused specifically on value creation. Authors talking about use value have referred to the specific quality of a new job, task, product, or service as perceived by users in relation to their needs, such as the speed or quality of performance on a new task or the aesthetics or performance features of a new product or service. The exchange value by Lepak, Smith and Taylor (2007) was defined as either the monetary amount realized at a certain point in time, when the exchange of the new task, good, service, or product takes place, or the amount paid by the user to the seller for the use value of the focal task, job, product, or service. Viewed together, these definitions suggest that value creation depends on the relative amount of value that is subjectively realized by a target user who is the focus of value creationwhether individual, organization, or society - and that this subjective value realization must at least translate into the user's willingness to exchange a monetary amount for the value received.

There already has been made a distinction between value creation and value appropriation, recognizing that, in some cases, organizations that create new value will lose or have to share this value with other stakeholders, such as employees, competitors, or society (Nohria \& Ghoshal, 1994; Makadok \& Coff, 2002; Chatain \& Zemsky, 2011; Porter \& Kramer, 2011). Framework for analyzing how frictions in the product market affect value creation and value capture might be adoptable in this case. Researching value creation through CSR, Porter and Kramer (2011) suggested concept of shared value. Shared value is defined as policies and operating practices that enhance the competitiveness of a company while simultaneously advancing the economic and social conditions in the communities in which it operates. Shared value creation focuses on identifying and expanding the connections between societal and economic progress. Quite related approach was given even earlier by Nohria and Ghoshal (1994) - it was named as creating share value. The main idea was that company success and social welfare are interdependent. According to this approach, some 
factors such as healthy, educated workforce, sustainable tangible and intangible resources and adept government are needed to compete effectively. Conclusively to all of that, we can indicate four value types, which might be created through CSR as shown in Table 1.

Table 1. Possible value types

\begin{tabular}{|l|l|l|}
\hline & \multicolumn{1}{|c|}{ Shared } & \multicolumn{1}{c|}{ Non Shared (individual) } \\
\hline Use & Use shared value & Used non shared value \\
\hline Exchange & Exchange shared value & Exchange non shared value \\
\hline
\end{tabular}

Porter and Kramer (2011) state, that companies can create economic value by creating societal value. Authors see three key ways that companies can create shared value opportunities:

- by reconceiving products and markets

- by redefining productivity in the value chain

- by enabling local cluster development

Creating shared value (CSV) should supersede corporate social responsibility (CSR) in guiding the investments of companies in their communities. CSR programs focus mostly on reputation and have only a limited connection to the business, making them hard to justify and maintain over the long run. In contrast, CSV is integral to a company's profitability and competitive position. It leverages the unique resources and expertise of the company to create.

Some scientists (Rivoli \& Waddock, 2011; Vaitkevičius \& Stukaitè, 2009; Valackienė \& Micevičienė, 2011) acknowledge that corporate social responsibility (CSR) discussions often fall into to a logical trap. If some socially desirable activity is profitable, then it is best described as "intelligent operation of the business". If the socially desirable activity is not profitable, then companies will not voluntarily undertake it unless required to do so by law or regulation. When private profits and public welfare are aligned, CSR seems to be irrelevant. Companies will undertake this activity driven by their self-interest, even if they call their actions as CSR, and shared value will be created. Such value creation through CSR seems to be more sustainable, because it's emergence less depends on corporate interests and government regulations. If company adopts CSR concept in it's business activity, there is a great probability that shared value will be created. That value might emerge as use or as exchange value. Therefore all attention in this paperwork is focused on shared value creation through CSR.

\section{Relations and responsibilities of stakeholders in the aspect of CSR}

It is far well acknowledged that the CSR consists of four kinds of responsibilities: economic, legal, ethical, and philanthropy (Carroll, 1999; Aras \& Aybars, 2010; Gholami, 2011; Valackienè \& Micevičienè, 2011). Authors suggested different variables to reveal value in each part of CSR. It was offered that full disclosure, equal positions for employees, philanthropy, environmental actions, and quality of products and services can be as variables to measure four types of CSR. Gholami (2011) consisted all of four types of CSR's dimensions including economic, legal, ethical, and philanthropic dimensions in his new framework of value creation cycle. The economic dimensions focus on obligations for businesses to create wealth and to face consumption requirements. This dimension is the foundation upon for other dimensions. The new framework suggests personal saving rate, business saving rate, inflation rate, and manufacturing lead time indicators to measure the economic dimension. The legal responsibilities dimension emphasize which the process of business should execute the vision and mission of their economic according to legal requirements (Gholami 2011). Ethical responsibilities focus on businesses abides that to do what is right, just and fair. Moral rules should define as suitable behaviors in the organizations and society. The philanthropic responsibilities are called discretionary responsibilities emphasize be a good corporate citizen. And likewise focus on contribution resources for community and improve quality of life as a basic indicator for community.

Other scholars (Maignan \& Ralston 2002; Aguilera et al., 2004) additionally noted that there are some interaction plays in CSR relationship:

- corporate - stakeholders,

- corporate - governments,

- corporate - environment,

- corporate - ethical, 
- corporate - sustainable competitive advantage.

According to the Normann and Ramirez (1993) studies, value creation system is consisted of different economic players or actors. These actors are suppliers, business partners, customers that work together to coproduce value for their organizations and society. Organization interaction scheme suggested by Susnienè and Vanagas (2005) take into account quite similar relationships parties: suppliers, personnel, customers and business associations. Developing conceptual model of value creation through CSR, all those relationship parties should be holistically combined as stakeholders. Company shareholders (investors) in this paper work are identified as company itself, because company directly represents and stands for interests of shareholders.

Table 2. Responsibilities and relations in CSR

\begin{tabular}{|c|c|c|c|c|c|c|c|c|}
\hline \multirow{2}{*}{ Relations with } & \multicolumn{4}{|c|}{ Stakeholders } & \multirow{2}{*}{ 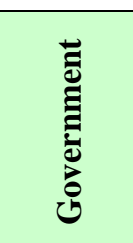 } & \multirow{2}{*}{ 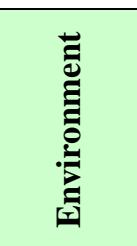 } & \multirow{2}{*}{ 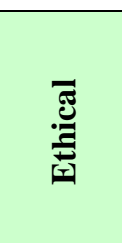 } & \multirow{2}{*}{ 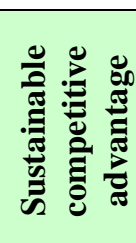 } \\
\hline & Suppliers & Customers & Personnel & $\begin{array}{c}\text { Business } \\
\text { associations }\end{array}$ & & & & \\
\hline Economic & Table 1. & Table 1. & Table 1. & Table 1. & Table 1. & Table 1. & Table 1. & Table 1. \\
\hline Legal & Table 1. & Table 1. & Table 1. & Table 1. & Table 1. & Table 1. & Table 1. & Table 1. \\
\hline Ethic & Table 1. & Table 1. & Table 1. & Table 1. & Table 1. & Table 1. & Table 1. & Table 1. \\
\hline Philantropic & Table 1. & Table 1. & Table 1. & Table 1. & Table 1. & Table 1. & Table 1. & Table 1. \\
\hline
\end{tabular}

Value creation essentially is possible in every relationship and responsibility conjunction point as shown in Table 2. In each of such conjunction value might emerge in for types as in described in Table 1. According Juščius (2008), Česynienè et al., (2011) and other scholars, company personnel is the main group of stakeholders when talking about CSR, because they have crucial impact to CSR process. But in any case, personnel are not the single stakeholder's group meaningful in value creation through CSR - other stakeholders must be researched as well.

\section{CSR implementation as value creation possibility}

Speaking about value creation there is important point of view that CSR is becoming a business strategy and not only a theory (Juščius, Pukelienè and Šneiderienė, 2009). Furthermore most of recently performed empiric CSR researches focus on value received by companies. Though, value for stakeholders mostly remains as a secondary topic. Talking about financial value created through CSR, more outstanding view was presented by Vyser (2010), Margolis and Walsh (2001) who said that, value creation through CSR is more than just financial profitability. The goal is economic development, which means not only contributing to the enrichment of shareholders and executives, but improving the economic context in which a company operates, including investing in infrastructure, creating jobs, providing skills development and so on. Furthermore company benefits received through CSR could be generally grouped into:

- financial value - Griffin \& Mahon (1997), Margolis \& Walsh (2001), Aybars \& Kutlu (2010), Vyser (2010), Ioannou \& George (2010).

- competitive advantage - Juščius \& Snieška (2008), Ruževičius \& Serafinas (2007), Georgiev (2009), Quyang (2011), Verma (2011), Du et al., (2010)

- favorable purchase decision making - Hietbrink et al., (2010), Banyte et al., (2010), Šimanskiené \& Paužuolienè (2010).

Apart those value creation possibilities through CSR, scholars note quite many problems especially related to CSR and stakeholders conjunction. Juščius (2007), Yuan et al., (2011) pointed the situation that, societal stakeholders' increasingly demand for CSR initiatives, and simultaneous corporate managers require that any such initiatives should improve business performance. Such situation has triggered various alternative strategies to integrate CSR in prevailing business activities, but not all of them are successful. If a company can't create value through CSR implementation, it might be because CSR was adopted into business activity not in the best way as it could be. Yuan, Bao and Verbeke (2011) have developed a new organizing framework with seven patterns showing how company can integrate CSR initiatives in business. Within the new framework, each of the pattern represents an idiosyncratic path through which recurring CSR initiatives can be included as practices into conventional operations. 
CSR initiatives, many based on either a proactive or reactive strategy (Rick, 2005; Šimanskiene \& Paužuolienè, 2010). Firms pursuing a proactive agenda actively engage in and support CSR prior to any negative information being received by consumers (Du et al., 2007). Conversely, a reactive strategy involves engaging in CSR to protect the image of the organization (i.e., mitigate harm) after some irresponsible action has been reported (Wagner et al., 2009). Groza et al., (2011) acknowledge that Corporate social responsibility (CSR) has emerged as an effective way for firms to create favorable attitudes among consumers. Author supports the idea that by engaging proactively in CSR firms can yield more favorable attitudinal responses from consumers than by acting in a reactionary manner. Findings as well suggest that in order to maximize positive returns from CSR investments, firms should take enhanced measures to release proactive CSR information from internal sources (Groza et al., 2011).

Theoretical and empiric researches confirm that value creation through CSR is feasible independently to company size particularly on the factors that translate into marketing benefits (Bocquet \& Mothe, 2011; Vancheswaran \& Gautam, 2011). As it is confirmed, small companies can also introduce radical innovation based on their CSR involvement. Results advise that small companies should decide which dimension of CSR is central to their strategy, and how they could use their strategic CSR to develop radical innovation, thus taking advantage of their CSR orientation to further develop value creation and innovation performance.

Vyser (2010) argues that CSR has failed and points three fundamental failings: peripheral CSR, incremental CSR and uneconomic CSR. Analyzing value creation through CSR the most important failing seems to be economic. Vyser (2010) notes that CSR does not always make economic sense, as the short-term markets still reward companies that externalize their costs to society. Quite similar approach is presented by Guzavičius \& Bruneckienè (2010), who emphasize the importance of information provided by stakeholders. There might be significant difference in information provided to stakeholders and society while both are decision makers in value creation process. Therefore predictions might be found that new era of CSR is coming and value creation through CSR will be possible if CSR will have new properties: creativity, scalability, responsiveness, glocality (globality) and circularity.

\section{Conclusions}

As theoretical researches show, value can be created through CSR implementation as in large as well as in small companies. Though, not always CSR helps to achieve desired benefits, effective communication of CSR implementation is stressed as one of major factors of value creation through CSR. It should lead to further discussions about CSR implementation strategies and capture of created value.

As concluding theoretical assumptions about value creation, it should be noted that different type value might emerge. Attention should be paid, that according most scholars, only shared value creation through CSR seems to be sustainable. It's already foreseen that CSR will evolve and value creation through CSR will change. Most likely, implementation of CSR will become more oriented towards creation of shared value.

There are quite many publications which generally concludes, that benefits from CSR implementations received by company remain in the center of most researches and might be grouped into two major trends: financial value and marketing benefits. Therefore value for stakeholders comes only as secondary object. Especially controversial situation is noted with company personnel - it is named as probably the most influential stakeholders group talking about value creation through CSR, but yet value received by this stakeholders group is not so widely researched in economic aspect.

The scientific problem on the interaction between corporate social responsibility and value creation for stakeholders still remains opened for the academic theoretical and empiric research. This paperwork leads that special framework for value creation through CSR might be developed to encourage further research of this topic.

\section{References}

1. Aguilera, R., \& Rupp, D., et al. (2004). Putting the S back in corporate social responsibility: A multi-level theory of social change in organizations. Academy of Management Review.

2. Aras, G., \& Aybars A., et al. (2010). Managing corporate performance: Investigating the relationship between corporate social responsibility and financial performance in emerging markets. International Journal of Productivity and Performance Management, 59(3): 229-254.

3. Banyte J., Brazioniene L., \& Gadeikiene A. (2010) Expression of Green Marketing Developing the Conception of Corporate Social Responsibility. ISSN 1392 - 2785 Inzinerine Ekonomika-Engineering Economics. (5), 550-560 
4. Bocquet, R., \& Mothe, C. (2011). Exploring the relationship between CSR and innovation: A comparison between small and largesized French companies. Revue Sciences de Gestion, Issue 80, 101-119.

5. Bowman, C., \& Ambrosini, V. (2000). Value creation versus value capture: Towards a coherent definition of value in strategy. British Journal of Management, 11: 1-15.

6. Carroll, A. (1999). Corporate social responsibility. Business \& Society, 38(3): 268.

7. Chatain, O., \& Zemsky, P. (2011). Value Creation and Value Capture with Frictions. Strategic Management Journal, Vol. 32 Issue 11, 1206-1231.

8. Česynienė R., D. Diskienė \& Česynaitė E. (2011). Socialinė atsakomybė darbuotojų atžvilgiu: lyginamoji viešojo ir verslo sektorių analizè. Viešasis administravimas. (29), 19-26.

9. Du, S., Bhattacharya, C. B., \& Sen., S. (2010). Maximizing Business Returns to Corporate Social Responsibility (CSR): The Role of CSR Communication. International Journal of Management Reviews, Vol. 12 Issue 1, 8-19.

10. Du, S., Bhattacharya, C. B., \& Sen, S. (2007). Reaping Relational Rewards from Corporate Social Responsibility: The Role of Competitive Positioning. International Journal of Research in Marketing 24(3), 224-241.

11. Gholami, S. (2011). Value Creation Model through Corporate Social Responsibility (CSR). International Journal of Business and Management Vol. 6, No. 9.

12. Griffin, J.J., \& Mahon, J.F. (1997). The corporate social performance and corporate financial performance debate. Business \& Society, 36, 5.

13. Groza, M., Pronschinske, M., \& Walker, M. (2011). Perceived Organizational Motives and Consumer Responses to Proactive and Reactive CSR. Journal of Business Ethics, Vol. 102 Issue 4, 639-652.

14. Guzavičius A., \& Bruneckienè J. (2010). Ekonominių interesų grupių socialinė atsakomybė teikiant asimetrinę informaciją. Economics \& Management, 520-524.

15. Hietbrink, J. J., Berens, G., \& Renkom J. (2011) Corporate Social Responsibility in a Business Purchasing Context: The Role of CSR Type and Supplier Product Share Size. Corporate Reputation Review, Winter2011, Vol. 13 Issue 4, 284-300.

16. Ioannou, I., \& Serafeim, G.. (2010). The Impact Of Corporate Social Responsibility on Investment Recommendations. Working Papers - Harvard Business School Division of Research. 1-45.

17. Yuan, W., Bao, Y., \& Verbeke, A. (2011) Integrating CSR Initiatives in Business: An Organizing Framework. Journal of Business Ethics, Vol. 101 Issue 1, 75-92.

18. Juščius, V., \& Snieška, V. (2008). Influence of Corporate Social Responsibility on Competitive Abilities of Corporations. Inzinerine Ekonomika-Engineering Economics(3), 34-44.

19. Juščius V. (2007). Corporate Social Responsibility and Sustainable Development. Organizacijų vadyba: sisteminiai tyrimai. (44), 35-44.

20. Juščius V. (2008) İmonių socialinès atsakomybės ittaka žmogiškujų išteklių konkurencingumui. Ekonomika ir vadyba.13, 526-531.

21. Juščius V., Pukelienè V., \& Šneiderienė A. (2009). Imonių socialinė atsakomybė tarptautinių kompanijų veikloje. Applied Economics: Systematic Research. Vol. 3 Issue 1, 175-192.

22. Lepak, D. P., Smith, K. G., \& Taylor, M.S. (2007). Academy of Management Review. Vol. 32 Issue 1, $180-194$.

23. Maignan, I., \& Ralston, D. (2002). Corporate social responsibility in Europe and the US: Insights from businesses self-presentations. Journal of International Business Studies, 33(3), 497-514.

24. Makadok, R., \& Coff, R. (2002). The theory of value and the value of theory: Breaking new ground versus reinventing the wheel. Academy of Management Review. (27), 10-13.

25. Margolis, J.D., \& Walsh, J.P. (2001). People and Profits? The Search for a Link between a Company's Social and Financial Performance. Mahwah, N.J.: Lawrence Erlbaum Associates.

26. Nohria, N., \& Ghoshal, S. (1994). Differentiated fit and shared values: Alternatives for managing headquarters subsidiary relations. Strategic Management Journal. 15(6), 491-502.

27. Normann, R., \& Ramirez, R. (1993). From value chain to value constellation: designing interactive strategy. Harvard business review, (71), 65-65.

28. Ouyang, Y. (2011) An Exploration of LMX and Personal Guanxi on Job Performance: the Mediating Effects of CSR. Journal of Global Business Issues, Vol. 5 Issue 1, 1-10.

29. Porter, M. E., \& Kramer, M. R. (2011). Creating Shared Value. Harvard Business Review. Vol. 89 Issue 1/2, p6277.

30. Ricks, J. M. Jr. (2005). An Assessment of Strategic Corporate Philanthropy on Perceptions of Brand Equity Variables. Journal of Consumer Marketing, 22(3), 121-134. 
31. Ruževičius J., \& Serafinas D. (2007). The Development of Socially Responsible Business in Lithuania. Inžinerinė Ekonomika-Engineering Economics, (51), 36-43.

32. Susnienè D., \& Vanagas P. (2005). Integration of total quality management into stakeholder management policy and harmonization of their interests // Engineering Economics, (4), 71-77.

33. Šimanskienė L., \& Paužuolienè J. (2010). Imonių socialinès atsakomybès svarba lietuvos organizacijoms. Management Theory \& Studies for Rural Business \& Infrastructure Development. Vol. 20 Issue 1, 138-145.

34. Vaitkevičius S., \& Stukaitė D. (2009). Imonių socialinės atsakomybès formavimas racionalaus veikimo kontekste. Ekonomika ir vadyba. 624-632.

35. Valackienè A., \& Micevičiené D. (2011). Methodological Framework Analysing a Social phenomenon: Stakeholder Orientation Implementing Balanced Corporate Social Responsibility. Inzinerine EkonomikaEngineering Economics, 22(3), 300-308.

36. Vancheswaran, A., \& Gautam, V. (2011). CSR in SMEs: Exploring a Marketing Correlation in Indian SMEs. Journal of Small Business and Entrepreneurship, v. 24, iss. 1, 85-98.

37. Verma, S. (2011). Why Indian Companies Indulge in CSR? Journal of Management \& Public Policy, Vol. 2 Issue 2, 52-69.

38. Visser, W. (2010). The Age of Responsibility: CSR 2.0 and the New DNA of Business. Journal of Business Systems, Governance \& Ethics, Vol. 5 Issue 2, 7-22.

39. Wagner, T., Lutz, R. J., \& Weitz, B. A. (2009). Corporate Hypocrisy: Overcoming the Threat of Inconsistent Corporate Social Responsibility Perceptions. Journal of Marketing, 73(6), 77-91. 